\title{
PENINGKATAN PRESTASI BELAJAR SISWA DALAM \\ PEMBELAJARAN KIMIA DENGAN PENERAPAN COOPERATIVE LEARNING MODEL JIGSAW PADA KELAS X IPA3 DI SMA NEGERI 1 PADANG
}

\author{
Prima Aswirna \\ Dosen Fakultas Tarbiyah IAIN Imam Bonjol Padang \\ e-mail: primaaswirna@yahoo.co.id
}

\begin{abstract}
The problem of this Classroom Action Research is how Cooperative Learning Model Jigsaw should be implemented in the learning of Chemistry at Grade X, Scince 3 of Senior High School 1 Padang. This study was done through the following stages such as Planning, Action, Observation, and Evaluation or Reflection. The results show among other that some important aspects were improved. The average score of each cycles show improvement in students' mastery and total average of the three actions become 98 percent. It can be concluded that Cooperative Learning through Jigsaw technique improved students' achievement of the subject being investigated.
\end{abstract}

\begin{abstract}
Abstrak: Masalah PTK dalam penelitian ini adalah untuk melihat bagaimana penerapan Cooperative Learning Model Jigsaw dalam pembelajaran kimia di kelas pada kelas X IPA 3 SMA Negeri 1 Padang. Penelitian PTK ini dilakukan dengan tahap-tahap: Perencanaan, Pelaksanaan. Observasi, dan Evaluasi dan Refleksi. Hasil penelitian adalah ada beberapa aspek yang sangat penting dalam pembelajaran berhasil ditingkatkan dengan menggunakan penerapan Cooperative Learning Model Jigsaw. Hasil evaluasi rata-rata tiap siklus menunjukkan ketuntasan belajar meningkat dan rata-rata dari tiga tindakan menjadi $98,0 \%$. Dapat disimpulkan penerapan Cooperative Learning Model Jigsaw dapat meningkatkan prestasi belajar siswa kelas X IPA 3 SMA Negeri 1 Padang
\end{abstract}

Kata Kunci : Cooperative Learning Tipe Jigsaw, Prestasi Belajar dan Pembelajaran Kimia

\section{PENDAHULUAN}

Kualitas pendidikan di Indonesia mengalami peningkatan. Hal itu disebabkan oleh adanya perbaikan kurikulum. Pada saat ini kurikulum yang digunakan di Indonesia adalah Kurikulum Tingkat Satuan Pendidikan KTSP. Dalam KTSP sekolah memiliki otonomi untuk mengembangkan kurikulum sekolah. Pada satuan pendidikan SMA, salah satu materi pelajaran yang diajarkan adalah ilmu kimia. Beban yang diemban oleh sekolah, dalam hal ini adalah guru sangat berat, karena gurulah yang berada pada garis depan dalam membentuk pribadi anak didik. Dengan demikian sistem pendidikan di masa depan perlu dikembangkan agar dapat menjadi lebih responsif terhadap tuntutan masyarakat dan tantangan yang akan dihadapi di dunia kerja di masa mendatang.

Tersedianya perangkat pembelajaran merupakan salah satu faktor yang dapat menunjang proses pembelajaran berjalan dengan baik dan dapat meningkatkan mutu pendidikan. Hal ini sesuai dengan pendapat Nur (1999), bahwa perangkat pembelajaran mempermudah dan membantu guru dalam mempersiapkan dan melaksanakan kegiatan belajar mengajar di kelas. Perangkat ini menyediakan sejumlah strategi untuk mendorong siswa menggunakan gaya-gaya belajar berbeda. Sehingga dengan perencanaan yang seksama, kebutuhan untuk seluruh siswa dapat dipenuhi dalam kelas Sains. Pola pengajaran seperti yang telah diuraikan di atas, menjadi salah satu penyebab rendahnya prestasi akademik mata pelajaran kimia lulusan SMAN 1 Padang. Data hasil analisis ulangan harian kelas $X$, sebagaimana terlampir menunjukkan bahwa siswa yang belum tuntas secara individual 45.0 $\%$. Hasil test formatif tersebut menunjukkan bahwa prestasi belajar siswa masih dibawah rata-rata keberhasilan kelas dengan persentase sekurang-kurangnya mencapai lebih besar dari $65 \%$. hal ini menunjukkan prestasi belajar siswa 
dalam mata pelajaran kimia masih perlu ditingkatkan.

Upaya membenahi prestasi siswa dalam mata pelajaran kimia perlu dilakukan secara serius oleh guru kimia sebab guru kimia merupakan ujung tombak pelaksana pembelajaran di dalam kelas. Oleh sebab itu meningkatkan prestasi belajar siswa harus dilakukan oleh guru kimia dengan cara melakukan perubahan, inovasi, dan kreativitas baru dalam pembelajaran kimia.

Selama ini diakui secara objektif bahwa pembelajaran kimia memang terlalu bertumpu pada metode ceramah atau pun ceramah bervariasi. Kadangkala pula guru melakukan pembenahan dengan metode tanya jawab dan diskusi. Namun hasilnya masih kurang efektif. Sehingga guru kimia perlu menerapkan satu metode yang dapat mengoptimalkan seluruh sumber pembelajaran seperti; guru, siswa itu sendiri, maupun sesama siswa.

Metode tersebut tentu harus berbasis pada cooperative learning. Salah satu model dalam cooperative learning yang dinilai dapat meningkatkan prestasi belajar siswa pada mata pelajaran kimia adalah model jigsaw karena model jigsaw ini memberikan peluang dan kesempatan kepada siswa untuk menemukan sendiri pengetahuan yang menjadi tugasnya dan secara bersama-sama di dalam kelompok mengembangkan pengetahuan tersebut.

Pengetahuan yang ditemukan sendiri melalui model jigsaw pada akhirnya akan tertanam lama dalam benak siswa (siswa tidak mudah lupa sebab menemukan sendiri). Selain itu model jigsaw ini memberikan kesempatan pada siswa untuk melakukan semacam shearing antar kelompok dengan cara membentuk kelompok ahli. Sehingga melalui model jigswa ini bukan saja pembelajaran kimia berlangsung secara dinamis tetapi juga menarik karena adanya variasi kelompok asal dan kelompok ahli.

Bila dalam pembelajaran kimia dengan metode ceramah dan ceramah bervariasi, siswa memperoleh pengetahuan hanya melalui guru, maka melalui penerapan cooperative learning model jigsaw setiap siswa dapat memperoleh pengetahuan dari 4 (empat ) sumber sekaligus secara bersamaan, yaitu; 1. Dari siswa itu sendiri secara pribadi, 2. Siswa lain di dalam kelompok, 3. kelompok lain melalui kelompok atau tim ahli, dan 4. Dari guru sebagai fasilitator pembelajaran

Berdasarkan pemahaman inilah diyakini bahwa penerapan cooperative learning model jigsaw dinilai sangat tepat untuk meningkatkan prestasi belajar siswa dalam pembelajaran kimia di SMA Negeri 1 Padang terutama pada kelas X $\mathrm{IPA}_{3}$ yang prestasinya secara keseluruhan lebih rendah dibanding kelas $\mathrm{X}$ lainnya.

\section{METODOLOGI}

\section{Lokasi Penelitian}

Penelitian ini dilaksanakan pada SMA Negeri I Padang Provinsi Sumatera Barat. Subjek penelitian adalah siswa kelas $\mathrm{X} \mathrm{IPA}_{3}$ dengan jumlah siswa sebanyak 42 orang terdiri atas 18 laki-laki dan 24 perempuan

Pelaksanaan tindakan dilakukan pada waktu jam pelajaran kimia (sesuai jadwal pelajaran di SMA Negeri I Padang) pada kelas yang sudah ditetapkan yaitu $X \mathrm{IPA}_{3}$. Lama tindakan 6 pekan atau 6 kali peretemuan yang dibagi dalam dua siklus. Satu siklus tiga tindakan. Setiap tindakan dialokasikan waktu 2 jam pelajaran. Jadi jumlah keseluruhan jam pelajaran yang digunakan dalam PTK ini adalah 12 jam pelajaran.

\section{Faktor yang diteliti}

a. Faktor siswa: Melihat hasil prestasi belajar siswa setelah mengikuti tindakan (jigsaw) pada mata pelajaran kimia. Selain itu diamati pula respon siswa selama mengikuti KBM dengan tindakan jigsaw. Respon siswa yang perlu diamati seperti ketekunan, keseriusan, kerja sama dalam kelompok, kerjasama antar kelompok (tim ahli), kemampuan bertanya dan menjawab pertanyaan serta penghargaan terhadap kelompok lain

b. Faktor guru: Melihat cara guru merancang pembelajaran dengan model jigsaw termasuk mengidentifikasi bahan dan alat yang digunakan, perangkat pembelajaran, perangkat observasi dan evaluasi termasuk mencermati pelaksanaan tindakan secara cermat dan mendalam.

\section{Prosedur Kegiatan}




\section{a. Perencanaan}

Ada tiga tahapan dalam perencanaan PTK ini, yaitu: Tahap pertama, menyusun perangkat pembelajaran berupa skenario pembelajaran dan rencana pengajaran, menentukan sembilan sub pokok bahasan (materi) yang menjadi muatan tindakan. Penentuan materi ini disesuaikan dengan kurikulum dan perangkat pembelajaran terutama Analisis Materi Pelajaran (silabus), dan menyiapkan bahan dan alat pembelajaran serta menyiapkan media pembelajaran yang relevan.

Tahap kedua, membuat indikator rancangan pembentukan kelompok berdasarkan jenis kelamin, agama dan tentu saja tingkat prestasi/kemampuan akademik siswa. Pada tahap ini juga sudah disiapkan rancangan perubahan komposisi anggota kelompok sebanyak sembilan kali (tindakan) untuk menghindari kejenuhan kelompok

Tahap ketiga, membuat berbagai instrumen tindakan berupa instrumen observasi kegiatan guru dan kegiatan siswa dalam KBM dengan tindakan jigsaw, membuat instrumen evaluasi yang disesuaikan dengan tujuan pembelajaran khusus seperti termuat dalam perangkat pembelajaran khususnya rencana pengajaran

\section{b. Pelaksanaan}

Tindakan dilakukan sebanyak sembilan kali dalam tiga siklus. Sasaran tindakan adalah siswa, pemberi tindakan adalah guru dan jenis tindakan adalah cooperative learning model jigsaw. Guru sebagai pemberi tindakan mempunyai kegiatan untuk melaksanakan tindakan tersebut yang dibagi dalam tiga tahap, yaitu tahap awal (pembukaan/pendahuluan), tahap kegiatan inti, dan tahap akhir atau penutup. Demikian pula kegiatan siswa dibagi dalam tiga tahap (tahap awal, inti dan akhir)

Kegiatan guru pada tahap awal antara lain ; Menyampaikan salam, mengabsensi, manyampaikan judul materi dan pentingnya materi, mengemukakan tujuan pembelajaran, membangkitkan pengetahuan awal, membentuk kelompok, menjelaskan tugas siswa dalam kelompok, memotivasi siswa dan membagi sarana yang dibutuhkan. Sedangkan kegiatan siswa pada tahap awal, antara lain; Merespon salam, merespon absensi, memperhatikan tujuan, menyimak penjelasan materi, duduk berkelompok, mencatat dan memahami tugas kelompok, menerima lembar kerja/bahan yang diberikan guru.

Pada tahap kegiatan inti/pokok, guru melakukan beberapa kegiatan atau tindakan seperti: meminta siswa memahami lembar kerja, meminta siswa mengerjakan tugas sesuai lembar kerja, membantu dan membimbing siswa bekerjasama dalam kelompok, membentuk kelompok/tim ahli, meminta tim ahli menjelaskan hasil diskusinya pada kelompok awal, mengatur jalannya presentase, dan mengatur penanggap secara bergiliran. Adapun kegiatan siswa pada tahap kegiatan inti antara lain: memahami lembar kerja, mengerjakan tugas sesuai lembar kerja, melakukan cooperative, secara aktif berdiskusi dalam tim ahli, mensosialisasikan hasil diskusi tim ahli, melakukan presentasi, memberikan tanggapan terhadap kelompok lain

Selanjutnya dikemukakan kegiatan guru pada tahap akhir, yaitu: merespon hasil kerja kelompok dan presentase, menyimpulkan, melakukan evaluasi test formatif, dan mengakhiri pembelajaran. Sedangkan kegiatan siswa pada tahap akhir adalah, mencermati kesimpulan guru, membuat rangkuman secara mandiri, menyelesaikan pertanyaan test formatif, dan merespon salam penutup dari guru.

\section{c. Observasi}

Observasi dilakukan sebelum dan saat pelaksanaan tindakan. Sebelum tindakan yang diobservasi berupa kelengkapan pembelajaran guru termasuk lembar kerja dan media. Pada saat tindakan dilaksanakan yang diobservasi adalah kegiatan guru dalam melakukan tindakan mulai dari tahap awal, inti, dan akhir. Juga diobservasi respon siswa selama menerima tindakan terutama kerjasama antar siswa maupun tim ahli.

\section{d. Refleksi}

Refleksi dimaksudkan untuk mengidentifikasi kelebihan dan kelemahan tindakan yang telah dilakukan. Adapun sumber informasi untuk melakukan refleksi adalah hasil observasi kegiatan guru dan siswa serta hasil 
evaluasi tes tes formatif. Aspek yang sudah dinilai baik pada tindakan terdahulu dipertahankan pada tindakan selanjutnya, sedangkan kelemahan-kelemahan yang ada didiskusikan bersama kemudian mencari cara terbaik memperbaiki kelemahan tersebut. Dengan demikian peneliti menjadikan tahap refleksi ini sebagai medium revisi tindakan. Refleksi semakin dimatangkan setiap selesai satu siklus

\section{Teknik Pengambilan Data}

a. Sumber data: Siswa dan Guru

b. Jenis Data: Ada dua jenis data yang menjadi sasaran penelitian yaitu:

Data kualitatif, diperoleh dari hasil observasi kegiatan guru dan siswa pada setiap tindakan berupa lembar observasi dan disajikan dalam bentuk prosentase. Data kuantitatif diperoleh dari hasil evaluasi yang diberikan pada setiap akhir tindakan (test formatif-post tes), dan instrumen yang digunakan berupa tes hasil belajar.

\section{Teknik Analisis Data}

Dalam penelitian tindakan kelas, peningkatan prestasi belajar siswa sebagai hasil tindakan merupakan aspek paling diharapkan. Oleh sebab itu analisis yang dipergunakan berkaitan erat dengan analisis tentang prestasi belajar siswa seperti : analisis daya serap, ketuntasan belajar, dan nilai rata-rata. Adapun rumus yang digunakan sebagai berikut :

a.

Daya serap individu

b.

$$
\% \text { dayaserapndividtul } \frac{\text { Skonyangliperolqheserta }}{\text { Skomaksimsidal }} \times 10 \%
$$

c.

individu.

Ketuntasan belajar secara

Peserta dikatakan tuntas belajar secara individu bila memperoleh persentase daya serap individu $\geq 60 \%$ d.

Daya serap secara klasikal

$\%$ daycrerapecarklasiketl $\frac{\text { Skototapeserttes }}{\text { Skondeabelurudval }} \times 10 \theta_{c}$ e. Ketuntasan belajar secara

klasikal.

$\%$ ketuntasdorelaja $=\frac{\text { Jumlalsiswayangtuntas }}{\text { Jumlakelurulsiswa }} \times 10 \%$

Peserta dikatakan tuntas belajar secara klasikal bila memperoleh persentase daya secara klasikal $\geq 85 \%$ (Depdikbud, 1996: 25)

f. Rata-rata hasil belajar

Nilairata-rata $=\frac{\text { Jumlahilaiyangdiperoledelurukiswa }}{\text { Jumlahsiswa }}$

6. Indikator Kinerja

Indikator kinerja yang digunakan dalam penelitian ini adalah daya serap individual, ketuntasan klasikal, dan nilai ratarata. Pendekatan konstruktivisme dinilai berhasil meningkatkan prestasi belajar siswa jika setiap tindakan menghasilkan daya serap individual (ketuntasan individual) minimal $60 \%$ dan dikatakan tuntas belajar secara klasikal, jika $85 \%$ atau lebih siswa tuntas belajar. 
HASIL DAN PEMBAHASAN

Tabel 1

Hasil Pengamatan Kegiatan Guru dalam Pembelajaran model Jigsaw Siklus 1 dan 2 Tindakan 1, 2, 3

\begin{tabular}{|c|c|c|c|c|c|c|c|}
\hline \multirow{3}{*}{ No } & \multirow{3}{*}{ Kegiatan } & \multicolumn{6}{|c|}{ Skor tindakan tiap siklus } \\
\hline & & \multicolumn{3}{|c|}{1} & \multicolumn{3}{|c|}{2} \\
\hline & & 1 & 2 & 3 & 1 & 2 & 3 \\
\hline 1 & Melakukan aktivitas keseharian & 5 & 4 & 5 & 5 & 5 & 5 \\
\hline 2 & Menyampaikan topic & 4 & 4 & 4 & 5 & 4 & 5 \\
\hline 3 & Menyampaikan tujuan & 5 & 4 & 5 & 4 & 4 & 5 \\
\hline 4 & $\begin{array}{l}\text { Menjelaskan pentingnya materi dan } \\
\text { membangkitkan pengetahuan awal siswa }\end{array}$ & 4 & 3 & 4 & 4 & 5 & 4 \\
\hline 5 & Membentuk kelompok & 5 & 5 & 5 & 5 & 5 & 5 \\
\hline 6 & $\begin{array}{l}\text { Menjelaskan tentang tugas individu dan } \\
\text { kelompok sera tanggung jawab kelompok }\end{array}$ & 2 & 2 & 3 & 4 & 4 & 5 \\
\hline 7 & $\begin{array}{l}\text { Mengatur posisi duduk masing-masing } \\
\text { kelompok secara efektif dan efisien }\end{array}$ & 4 & 2 & 3 & 5 & 5 & 5 \\
\hline 8 & Menyediakan fasilitas yang dibutuhkan & 5 & 4 & 4 & 5 & 4 & 5 \\
\hline 9 & $\begin{array}{l}\text { Menjelaskan kepada siswa agar memahami dan } \\
\text { menyelesaikan LKS }\end{array}$ & 5 & 4 & 4 & 4 & 4 & 4 \\
\hline 10 & Membantu siswa menyelesaikan tugas & 2 & 3 & 3 & 4 & 4 & 4 \\
\hline 11 & $\begin{array}{l}\text { Membantu siswa saling mengajarkan hasil } \\
\text { yang telah dikerjakan }\end{array}$ & 2 & 3 & 4 & 4 & 4 & 4 \\
\hline 12 & Membentuk kelompok ahli & 2 & 3 & 4 & 4 & 4 & 5 \\
\hline 13 & $\begin{array}{l}\text { Memberikan kesempatan kepada kelompok } \\
\text { ahli melakukan sosialisasi }\end{array}$ & 3 & 4 & 3 & 4 & 4 & 4 \\
\hline 14 & $\begin{array}{l}\text { Meminta kelompok menyiapkan atau } \\
\text { merumuskan jawaban akhir }\end{array}$ & 2 & 3 & 4 & 4 & 5 & 5 \\
\hline 15 & Melaksanakan presentasi & 2 & 3 & 4 & 4 & 4 & 4 \\
\hline 16 & Mengatur tanggapan dan umpan balik & 2 & 4 & 3 & 3 & 4 & 4 \\
\hline 17 & Membantu kelancaran presentasi & 2 & 3 & 3 & 4 & 4 & 5 \\
\hline 18 & Merespon pembelajaran & 3 & 4 & 5 & 5 & 5 & 5 \\
\hline 19 & Melaksanakan evaluasi & 5 & 5 & 5 & 5 & 5 & 5 \\
\hline \multirow[t]{2}{*}{20} & Melaksanakan aktivitas keseharian & 4 & 4 & 4 & 5 & 5 & 5 \\
\hline & Jumlah & 66 & 71 & 80 & 87 & 88 & 93 \\
\hline
\end{tabular}

Berdasarkan tabel di atas dapat dilihat perkembangan kegiatan guru dalam setiap siklus melalui penerapan cooperative learning model jigsaw makin meningkat. Hal ini tidak lepas dari upaya perbaikan yang dilakukan guru berdasarkan saran dan hasil refleksi tiap siklus. Tentunya kegiatan guru pada setiap siklus dapat mempengaruhi kegiatan siswa dalam mengikuti pembelajaran. Untuk mengetahui hasil observasi kegiatan siswa, maka disajikan data berdasarkan tabel 2 di bawah ini: 
Tabel 2

Hasil Pengamatan Kegiatan Siswa dalam Pembelajaran Model Siklus 1 dan 2

\begin{tabular}{|c|c|c|c|c|c|c|c|}
\hline \multirow{3}{*}{ No } & \multirow{3}{*}{ Kegiatan } & \multicolumn{6}{|c|}{ Skor tindakan tiap siklus } \\
\hline & & \multicolumn{3}{|c|}{1} & \multicolumn{3}{|c|}{2} \\
\hline & & 1 & 2 & 3 & 1 & 2 & 3 \\
\hline 1 & 2 & 3 & 4 & 5 & 6 & 7 & 8 \\
\hline 1 & Melakukan aktivitas keseharian & 3 & 3 & 4 & 4 & 5 & 4 \\
\hline 2 & Mencermati topic & 3 & 4 & 3 & 4 & 4 & 5 \\
\hline 3 & Memperhatikan tujuan & 3 & 3 & 4 & 4 & 5 & 5 \\
\hline 4 & $\begin{array}{l}\text { Memperhatikan uraian materi dan keterlibatan dalam } \\
\text { pembangkitan pengetahuan awal }\end{array}$ & 3 & 3 & 3 & 3 & 4 & 4 \\
\hline 5 & Keterlibatan dalam pembentukan kelompok & 3 & 3 & 4 & 5 & 4 & 5 \\
\hline 6 & Memahami tugas dan tanggung jawab kelompok & 2 & 3 & 3 & 4 & 4 & 4 \\
\hline 7 & duduk berkelompok & 4 & 3 & 4 & 5 & 5 & 5 \\
\hline 8 & Menerima fasilitas pembelajaran & 4 & 4 & 5 & 5 & 5 & 5 \\
\hline 9 & Memahami LKS & 4 & 4 & 4 & 5 & 5 & 5 \\
\hline 10 & Menyelesaikan tugas & 2 & 3 & 3 & 3 & 2 & 4 \\
\hline 11 & Sharing dalam kelompok & 3 & 3 & 3 & 4 & 3 & 4 \\
\hline 12 & Keterlibatan dalam kelompok ahli & 3 & 3 & 3 & 4 & 4 & 4 \\
\hline 13 & Sosialisasi & 3 & 3 & 4 & 3 & 3 & 3 \\
\hline 14 & Menyiapkan rumusan jawaban akhir/laporan & 3 & 3 & 3 & 4 & 4 & 4 \\
\hline 15 & Mengikuti presentasi & 3 & 3 & 3 & 3 & 4 & 4 \\
\hline 16 & Memberi tanggapan dan umpan balik & 3 & 3 & 3 & 3 & 3 & 3 \\
\hline 17 & Keterlibatan dalam Membantu kelancaran presentasi & 3 & 4 & 3 & 3 & 3 & 3 \\
\hline 18 & Merespon pembelajaran & 3 & 3 & 3 & 4 & 3 & 4 \\
\hline 19 & Mengikuti evaluasi & 4 & 4 & 5 & 4 & 3 & 4 \\
\hline \multirow[t]{2}{*}{20} & Melaksanakan aktivitas keseharian & 4 & 5 & 5 & 5 & 5 & 5 \\
\hline & Jumlah & 63 & 67 & 68 & 84 & 88 & 89 \\
\hline
\end{tabular}

Dari tabel di atas dapat dilihat pada semua aspek yang diamati mengalami peningkatan aktivitas siswa dalam mengikuti pembelajaran. Setelah memaparkan data siklus satu dan dua disertai dengan rincian kelebihan dan kelemahan, dapat dilihat bahwa hasil penelitian baik menyangkut aktivitas guru maupun siswa memperlihatkan kecenderungan peningkatan prestasi siswa yang sangat baik. Dengan kata lain hasil belajar siswa pada mata pelajaran kimia dengan menggunakan penerapan cooperative learning model jigsaw berhasil ditingkatkan. Untuk mengetahui dan membuktikan keberhasilan penerapan pendekatan kontruktivisme dalam pembelajaran Kimia meningkatkan prestasi belajar siswa maka disajikan tabel berikut yang berisikan tentang hasil evaluasi mulai dari tindakan pertama siklus satu sampai dengan tindakan tiga siklus dua (6 tindakan). Data tersebut dibuat per siklus yaitu siklus satu tabel, siklus dua pada tabel 3.2 dan pada tabel 3.3 siklus tiga, agar dapat dilihat secara langsung peningkatan hasil belajar tersebut tiap siklus. 
Tabel 3.

Hasil Evaluasi Siswa siklus 1 dan siklus 2

\begin{tabular}{|c|c|c|c|c|c|c|c|c|}
\hline \multirow{2}{*}{ Nilai } & \multicolumn{3}{|c|}{ Siklus 1 Tindakan } & \multirow{2}{*}{$\begin{array}{l}\text { Rata-rata } \\
\text { siklus } 1\end{array}$} & \multicolumn{3}{|c|}{ Siklus 2 Tindakan } & \multirow{2}{*}{$\begin{array}{l}\text { Rata-rata } \\
\text { siklus } 2\end{array}$} \\
\hline & 1 & 2 & 3 & & 1 & 2 & 3 & \\
\hline Jumlah & 2.671 & 2.745 & 2.916 & $2.747,4$ & 3.132 & 3.070 & 3.062 & $3.157,4$ \\
\hline Daya serap & 63,6 & 67,0 & 69,4 & 65,4 & 74,5 & 74,9 & 76,6 & 75,2 \\
\hline Rata-rata & 63,6 & 67,0 & 69,4 & 65,4 & 74,5 & 74,9 & 76,6 & 75,2 \\
\hline$\%$ Ketuntasan & 73,8 & 85,5 & 92,9 & 90,5 & 92,9 & 100 & 95,0 & 98.0 \\
\hline
\end{tabular}

Berdasarkan data tersebut, dapat dijawab sekaligus dibahas permasalahan PTK yang telah dirumuskan pada bagian pendahuluan. Permasalahan apakah penerapan cooperative learning model jigsaw dapat meningkatkan prestasi belajar siswa kelas $\mathrm{X}$ $\mathrm{IPA}_{3}$ SMA Negeri 1 Padang khususnya pada pelajaran kimia. Peningkatan prestasi belajar dapat dilihat dari hasil evaluasi tiap tindakan (rata-rata, daya serap dan ketuntasan klasikal).

Hasil penelitian khususnya hasil evaluasi menunjukkan bahwa daya serap siswa cenderung mengalami peningkatan bila menerapkan cooperative learning model jigsaw dalam pembelajaran kimia. Pada siklus satu untuk tindakan pertama berhasil dicapai daya serap sebesar 63,6, tindakan kedua naik menjadi 67,0, tindakan ketiga menjadi 69,4. Sedangkan pada siklus kedua untuk tindakan pertama daya serapnya 74,5 yang berarti naik dari tindakan sebelumnya pada siklus satu. Tindakan kedua menjadi 74,9 dan pada tindakan ketiga berhasil dicapai daya serap 76,6.

Berarti terjadi peningkatan daya serap dalam pembelajaran kimia dengan menerapkan cooperative learning model jigsaw. Demikian pula halnya dengan ketuntasan klasikal. Ketuntasan setiap individu ditentukan nilai 65 . (sesuai KKM di SMAN 1 Padang dengan skor maksimal 100). Pada siklus satu untuk tindakan pertama hanya mencapai $73,8 \%$ yang berarti pula sudah memenuh standar ketuntasan klasikal meskipun masih ada 10 orang siswa tidak tuntas secara individual, lalu pada tindakan kedua menjadi 85,5\% yang berarti 6 siswa tidak tuntas secara individu dan pada tindakan ketiga naik lagi menjadi 92,9 \% yang berati tiga siswa tidak tuntas secara individu. . Selanjutnya kenaikan ketuntasan klasikan semakin tampak pada siklus kedua. Siklus dua untuk tindakan pertama ketuntasan klasikalnya mencapai 92,9 \% (3 siswa tidak tuntas secara individu, tindakan kedua menjadi $100 \%$ dan tindakan ketiga menjadi 95,0 \% yang berarti tinggal 2 siswa yang tidak tuntas secara individu. Artinya terjadi peningkatan ketuntasan klasikal.

Berdasarkan uraian di atas, maka berhasil dibuktikan bahwa penerapan cooperative learning model jigsaw dapat meningkatkan daya serap dan ketuntasan klasikal, yang berarti prestasi belajar siswa terbukti meningkat. Hal ini dapat pula dilihat dan dibuktikan berdasarkan peningkatan hasil belajar siswa.

Data yang ada menunjukkan bahwa pada siklus satu untuk tindakan pertama berhasil diperoleh nilai rata-rata 63,6 , tindakan kedua naik menjadi 67,0 , dan tindakan ketiga naik lagi menjadi 69,4. Selanjutnya pada siklus kedua tindakan pertama berhasil diperoleh nilai ratarata sebesar 74,5, tindakan kedua 74,9 dan tindakan ketiga 76,6. Berarti secara keseluruhan semua tindakan cenderung mengalami peningkatan hasil belajar siswa. Oleh sebab itu disimpulkan penerapan cooperative learning model jigsaw dalam pembelajaran kimia dapat meningkatkan hasil belajar siswa.

\section{SIMPULAN}

Berdasarkan hasil penelitian tindakan kelas di kelas $\mathrm{X} \quad \mathrm{IPA}_{3}$ SMA Negeri 1 Padang dapat disimpulkan bahwa penerapan cooperative learning model jigsaw dapat meningkatkan prestasi belajar siswa khususnya siswa kelas $\mathrm{X} \quad \mathrm{IPA}_{3}$ SMA Negeri 1 Padang. prestasi belajar siswa kelas X IPA3 SMA Negeri 1 Padang pada mata pelajaran kimia dapat ditingkatkan bila digunakan pendekatan cooperative learning model jigsaw. Hal ini dapat dibuktikan dengan dua indikator yaitu nilai rata-rata persiklus dan ketuntasan klasikal 
persiklus. Untuk nilai rata-rata, siklus satu nilai rata 65,4 dengan ketuntasan klasikal 90,5\%. Pada siklus dua nilai rata-rata naik lagi menjadi 75,2 dengan ketuntasan klasikal 98\%. Dengan demikian terbukti pendekatan cooperative learning model jigsaw dapat meningkatkan prestasi belajar siswa dalam pembelajaran kimia di kelas X IPA 3 SMA Negeri 1 Padang.

\section{DAFTAR RUJUKAN}

Carin, A. 1993. Teaching Modern Science. New York: Macmillan Publishing Company.

Dees, Robert L, 1991. The Role of Cooperative Learning in Increasing Problem Solving Ability in a Collage Remedial Course, Juornal for Research in Mathematics Education, 22 (5);409 421.

Hill,Susan \& Hill, 1993. The Colaborative Classroom: A Guide to Cooperative Learning, Victoria; Elianor Curatain Publishing.

Johnson,D.W. \& Johnson, R.T, 1994. Learning Together and Alone; Cooperative, Competitive, and individualistic
Learning. Four Education. Massachusets; Allyn and Bacon

Karim, 2000. Kurikulum Berbasis Kompetensi. Jakarta: Pusat Kurikulum Balitbang Diknas.

Lie, Anita, 2004. Cooperative Learning. Memeraktekan Cooperative Learning di Ruang-ruang Kelas. Grasindo. Jakarta.

Loisell, R. D, Descamps, J. 1992. Devoloping a Teaching Sty;e Method for Elementary School Teachers. New York; Harper Collins Publishers.

Riyanto, Milan, 1996. Perangkat Pembelajaran. Depdikbud,PPPG Malang.

Slavin, Robert E, 1995. Cooperative Learning. Second Edition. Massachusets Allyn \& Bacon.

Surachmad, Winarno. 1987. Metodologi Pengajaran Nasional. Jenmers. Jakarta

Tilaar, H. 1997. "Paradigma Baru Pendidikan Nasional". Editor: Ali Saukah. Jurnal

Ilmu Pendidikan, Jilid 7 Desember 1997. Jakarta: LPTK \& ISPI.

www.oke.or.id/ Diakses tanggal 12 Agustus 2012.

Zainal Arifin. 1991. Evaluasi Pendidikan. Remaja Rosdakarya. Bandung. 